\title{
LY6E wt Allele
}

National Cancer Institute

\section{Source}

National Cancer Institute. LY6E wt Allele. NCI Thesaurus. Code C51550.

Human LY6E wild-type allele is located in the vicinity of $8 \mathrm{q} 24.3$ and is approximately $4 \mathrm{~kb}$

in length. This allele, which encodes lymphocyte antigen Ly-6E protein, is involved in myelopoiesis and signal transduction. 